\title{
Behavior of humpback whales, Megaptera novaeangliae (Cetacea: Balaenopteridae): comparisons between two coastal areas of Brazil
}

\author{
Diana G. Lunardi ${ }^{\text {; }}$ Márcia H. Engel ${ }^{2} \&$ Regina H. F. Macedo ${ }^{3}$ \\ 1 Programa de Pós-Graduação em Psicobiologia, Departamento de Fisiologia, Centro de Biociências, Universidade Federal do \\ Rio Grande do Norte. Caixa Postal 1510, 59078-970 Natal, Rio Grande do Norte, Brasil. E-mail: lunardi.diana@gmail.com \\ 2 Instituto Baleia Jubarte. Rua Barão do Rio Branco 26, 45900-000 Caravelas, Bahia, Brasil. \\ ${ }^{3}$ Departamento de Zoologia, Instituto de Ciências Biológicas, Universidade de Brasília, 70910-900 Brasília, Distrito Federal, Brasil.
}

\begin{abstract}
Behavior of humpback whales was observed during the reproductive period off the northern coast of the state of Bahia (NB, $n=378$ groups) and at the Abrolhos Bank $(A B, n=919)$ to compare patterns and group composition between the two locations. Alone individuals and dyads were most often encountered in both areas, although mother-calf pairs were more common in $A B$. While these two regions comprise distinct concentrations of humpback whales, with intrinsic environmental differences, behavior patterns were quite similar. The only behavioral differences found where for "tail up" and "resting". The patterns found here may reflect differences in the protection status of the areas or intrinsic environmental differences.

KEY WORDS. Abrolhos Bank; Bahia; Bayesian networks; Occidental South Atlantic; reproductive season.
\end{abstract}

RESUMO. Comportamento de baleias jubarte, Megaptera novaeangliae (Cetacea: Balaenopteridae): comparação entre duas áreas de concentração na costa do Brasil. Eventos e estados comportamentais de baleias jubarte durante a temporada reprodutiva foram observados no Litoral Norte da Bahia (LNB) e no Banco dos Abrolhos (BA), para identificar possíveis diferenças nos padrões comportamentais específicos a determinadas composições de grupo. Foram analisados 378 grupos de baleias jubarte no LNB e 919 no BA. Obteve-se uma predominância de duplas e animais solitários em ambas as áreas. No entanto, grupos de "fêmea e filhote" foram mais comumente observados no BA, quando comparados ao LNB. Apesar das duas áreas serem distintas quanto à concentração de baleias jubarte, com diferenças ambientais intrínsecas, obtiveram-se probabilidades de ocorrência das condutas bastante similares para ambas as áreas. Diferenças significativas na probabilidade de ocorrência foram obtidas apenas para as condutas "exposição da caudal" e "repouso". As diferenças obtidas neste estudo, comparando-se as duas regiões amostradas, possivelmente refletem diferenças no status de proteção da área e/ ou características ambientais intrínsecas a cada área.

PALAVRAS-CHAVE. Atlântico Sul Ocidental; Bahia; Banco dos Abrolhos; estação reprodutiva; Rede Bayesiana.

Group size for many species of vertebrates is influenced by a variety of ecological factors and group living may be favored by individual behavior. Group size reflects a balance between costs and benefits and the main factors that influence group size and social behavior are probably predation risk, resource abundance and parental care (KREBS \& DAVIES 1996).

Megaptera novaeangliae (Borowski, 1781), known in Brazil as "baleia jubarte", is found in all oceans. The humpback is the best-studied whale in the Mysticeti, yet still much remains to be studied. Humpbacks have distinct temporal geographical distribution patterns in which extensive migrations occur between feeding and breeding areas. Migration is associated with an ordered segregation of individuals that is based on factors such as social or age class (Chittleborough 1965, Dawbin 1966). The humpback prefers coastal habitats and tends to reproduce in traditional breeding grounds (CLAPHAM 2000). Habitat choice is governed by a complex interaction between behavior, biological requirements and environmental conditions, including water temperature and height of tides (RobBins et al. 2001). At Stellwagen Bank and six areas near the Gulf of Maine, habitat preferences are also associated with sex and age class (RobBins et al. 2001). Males were more commonly sighted north of the gulf of Maine (64\%) while females were most often seen further south (37\%) and calves and juveniles were more often seen south (13\%) as compared to northeast (4\%).

Habitat preference patterns in lower latitudes are apparently influenced by social organization, where the distribution of different group types is a function of proximity to the coast and water depth. At Antongil Bay, Madagascar, the mothercalf pair preferred shallower waters. Mother+calf were found

Revista Brasileira de Zoologia 25 (2): 159-164, June, 2008 
more often (60\%) in waters less than $20 \mathrm{~m}$ depth, while other dyads (61\%), competitive groups (62\%) and alone individuals $(67 \%)$ were found in deeper waters. Competitive groups were more often far from the coast as compared to mother+calf,and one escort and dyads (Ersts \& Rosenbaum 2003).

Locations where calves are reared are important predictors of future occupation patterns of those same calves (WEINRICH 1998). At Stellwagen Bank and Jeffreys Ledge, calves were more likely to reappear where they were reared (79 and 72\% respectively) than to appear at the other, nearby location.

Abrolhos Bank, in the state of Bahia, is the main area of humpback reproduction in the southwestern Atlantic Ocean, with densities that vary between 1.6-2.3 individuals per square nautical mile. The northern coast of Bahia, while less abundant (0.3-1.0 individuals per square nautical mile), is getting attention due to its potential for whale watching (C.C.A. Martins, pers. comm.).

In the southern hemisphere calving peaks in early August and each female may reproduce once every one to five years (mode $=2$; Chitrleborough 1958, 1965, Clapham \& Mayo 1987, 1990). The adult sex ratio is one to one (Chittleborough 1958), while tending towards more males in areas where reproduction occurs (Сhittleborough 1958, РАLSBØll et al. 1997).

Social organization of humpbacks in southern latitudes is usually that of small groups, where alone individuals, dyads and triads are common (Mobley \& Herman 1985, Clapham et al. 1992, Mattila et al. 1994, Martins et al. 2001, Morete et al. 2007). Brief and unstable associations are also common (Tyack \& WhiteHEAD 1983, Baker \& Herman 1984, Mobley \& Herman 1985). Competitive groups, where males compete for access to females, are often agonistic and interactions may commonly be observed at the water surface. Interactions can last several hours and are very dynamic, with new associations often forming and ending (Tyack \& Whitehead 1983, Baker \& Herman 1984, Clapham et al. 1992). TYACK \& WHITEHEAD (1983) and BAKER \& Herman (1984) were the first to describe competitive groups in detail and to understand their function. The central, less active, whale, called the nuclear animal (presumably female), is accompanied by a primary "escort": a male that may vigorously defend access to the female. Secondary escorts are the other whales in the group, except for calf when present.

Humpbacks are known for their frequent and energetic aerial displays. Another common behavior of competitive groups is bubblestreams (TYACK \& WHITEHEAD 1983, BAKER \& HERMAN 1984), perhaps to indicate quality of the primary escort to either the female or to other males, or both (CLAPHAM 2000). Also, other behaviors seem to be associated with visual and acoustic communication, such as breaching and lobtailing or flippering (WHiteHEAD 1985).

Comparisons of behaviors in distinct areas may help explain how functional differences in behavior reflect ecological differences in the locations. Abrolhos Bank is different from the northern coast because it is protected by law (Decree 88,218 of 6 April 1983 and 8,553 of 5 June 2003), is associated with a larger width of the continental shelf (FAINSTEIN \& Summerhayes 1982, Castro \& Miranda 1998) and has a different influence due to boats and ships, and so we expect whale behavior to also vary. In this study, we compared whale behavior and group composition in these two areas to test whether these differences between the areas are reflected in difference among behaviors and group structure.

\section{MATERIAL AND METHODS}

One of the study areas comprise the northern coast of the state of Bahia (NB), established in this study as northern limit at Subauma $\left(\sim 12.6^{\circ} \mathrm{S}\right)$ and southern limit at Salvador $\left(\sim 13^{\circ} \mathrm{S}\right)$. Here, coral reefs extend along a relatively straight 20 $\mathrm{km}$. This area is now a protected area - the Northern Coast of Bahia Continental Shelf Protected Area ("Área de Proteção Ambiental da Plataforma Continental do Litoral Norte da Bahia", state decree 8,553 of 5 June 2003). Humpback whales are generally found $1-12 \mathrm{~km}$ from the coast. The other study area is the Abrolhos Bank $\left(16^{\circ} 40^{\prime}-19^{\circ} 30^{\prime} \mathrm{S}, \mathrm{AB}\right)$, a wider area of the continental shelf. The region is shallow, with a complex topography and covers an area of approximately $30,000 \mathrm{~km}^{2}$ (Fainstein \& Summerhayes 1982). The "Arquipélago dos Abrolhos" comprises islands that became a National Marine Park (Decree 88,218 of 6 April 1983).

Definitions of social groups for the purposes of this study are as follows: a group is one or more individuals the stay together during the observation period ( $30 \mathrm{~min})$, all within $100 \mathrm{~m}$ from the others, apparently coordinated and moving in the same direction (Whitehead 1983, Mobley \& Herman 1985); calves are those that stay next to an adult, less than $50 \%$ of the length of that adult (Chittleborough 1965, Corkeron 1995, Clapham 2000, MoRete et al. 2003, 2007); sub-adults (between 50-70\% of the adult length) were classified as adults due to the difficulty with which their lengths were measured. A competitive group is any that had three or more adult individuals.

Observations were carried out during 2001-2003, during July to October at NB and July to November at AB, months with typically the greatest abundance. Whales were found by naked eye or binoculars ( 7 x 50). Observations were suspended during bad weather, low visibility, rain or Beaufort scale $>5$. Once sighted, whales were observed, noting their initial and final locations and behaviors and group structure.

In the northern coast of Bahia, tourist and research boats were used to observe whales. A sailboat and a wooden schooner, with motor, were used for observations. Observation intervals were $361 \pm 142$ minutes daily (mean and standard deviation), with a minimum of three observers, each in their own location on the research boats, or one observer on tourist boats. Observations from tourist boats were variable, as they depended on the touring conditions.

At Abrolhos Bank, observations were from research vessels (schooners and trawlers). Observations ( $404 \pm 146$ min day $^{-1}$ ) were 
in bouts of 30 minutes with a minimum of three observers at different points on the boat.

At both places, observation periods lasted approximately $30 \mathrm{~min}$, with occasional $15 \mathrm{~min}$ extensions when it was difficult to approach the group. Boats (and observers) maintained a distance of approximately $100 \mathrm{~m}$ from the whales.

Based on previous studies (TYACK \& WHITEHEAD 1983, BAKER \& Herman 1984, Clapham et al. 1992), social groups were classified in eight possibilities: 1) mother and calf; 2) mother, calf and escort; 3) mother, calf and two escorts; 4) mother, calf and $>2$ escorts; 5) alone adult; 6) two adults; 7) three adults; 8) more than three adults.

Behavioral data was gathered following Altmann (1974). Behavior was classified into one or more of six possibilities: 1) Traveling: diving or swimming (CORKERON 1995, Morete et al. 2003); 2) Resting: motionless at the water surface (Corkeron 1995, Morete et al. 2003); 3) Tail-up: at least one group member engaged in tail-up (Morete et al. 2003); 4) Socializing: at least one group member breaching or flippering (WHITEHEAD 1985); 5) Active: tail breaching or lobtailing (WHITEHEAD 1985, Clapham 2000); 6) Aggressive: agonistic behaviors, such as headlunging (BAKer \& Herman 1984), trumpet (Corkeron 1995), bubblestreams and tail slashes (TyACK \& WHITEHEAD 1983).

Bayesian analyses were chosen to estimate behavior probabilities. Thus, results can be put in the form of probability functions with interactions (CHARNIAK 1991). Mann-Whitney U was used to test for differences in group size in the two areas. Chisquare $\left(\chi^{2}\right)$ was used to test for different behaviors in the two locations. For the Bayesian analysis the program NETICA version 1.12 was used, and the remaining analyses used SPSS, version 11.5.

\section{Group Composition}

At NB, a total of 378 groups were studied during 143 days for a total of 861 hours of study. At AB, 919 groups were studied in 187 days and a total of 1,294 hours of study. Alone and dyad groups were most common (NB: alone, $\chi^{2}=6.77$, $\mathrm{p}=0.009 ;$ dyad, $\chi^{2}=38.23, \mathrm{p}<0.0001 ; \mathrm{AB}$ : alone, $\chi^{2}=61.77$, $\mathrm{p}<0.0001$; dyad, $\chi^{2}=101.72, \mathrm{p}<0.0001$, Fig. 1$)$. For the totals, groups with calves (mother and calf; mother, calf and escort; mother, calf and two escorts; mother, calf and $>2$ escorts) were more common at $\mathrm{AB}$ than $\mathrm{NB}\left(\chi^{2}=8.321, \mathrm{p}=0.004\right)$.

Competitive groups without calves were smaller at $\mathrm{NB}$ (3.7 \pm 1.42 adults/group) than at $\mathrm{AB}(4.15 \pm 1.48$ adults/group; Mann-Whitney, $U=4721.50, \mathrm{p}<0.007)$. However, other groups were similar in size between the two areas $\left(\chi_{1}^{2}=0.067, \chi_{2}^{2}=2.33\right.$, p > 0.05; Fig. 2).

\section{Behavior compared between areas}

The groups mother and calf, mother, calf and two escorts, mother, calf and $>2$ escorts were excluded from analyses due to small sample sizes. At NB there were four groups of mother, calf and two escorts, and two of mother, calf and $>2$ escorts, while at $\mathrm{AB}$ there were 12 groups of mother, calf and

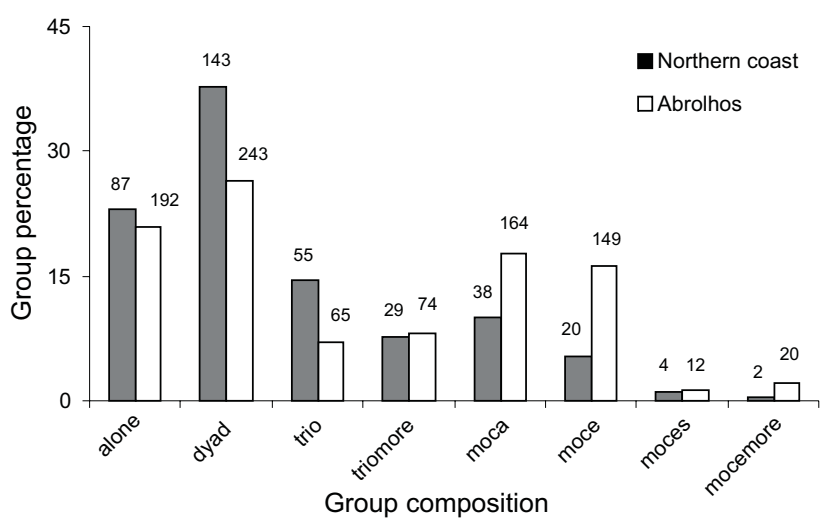

Figure 1. Percentage of humpback whale groups observed at the northern coast of Bahia and the Abrolhos Bank, from 2001 to 2003. Numbers at the tops of bars indicate the number of groups. Codes for group composition are: an alone individual (alone), two adults (dyad), three adults (trio), more than three (triomore), mother and calf (moca), mother, calf, and escort (moce), mother, calf and two escorts (moces), mother, calf and more than two escorts (mocemore).

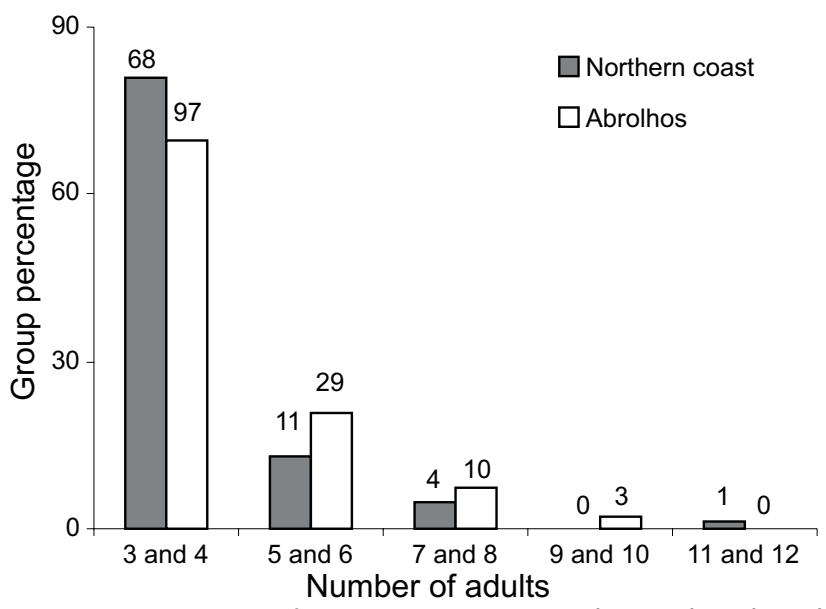

Figure 2. Percentage of competitive groups without calves, based on the number of adults comprising the group at the northern coast of Bahia and the Abrolhos Bank, from 2001 to 2003. Values over the bars indicated number of groups.

two escorts, and 20 of mother, calf and $>2$ escorts.

Differences in probability of behaviors were classified as not very significant $(<4 \%)$, significant (4-8\%), and strongly significant $(>8 \%)$. The difference in traveling, socializing, active and aggressive were not very significant. Tail-up display $(\mathrm{AB}=$ $10 \%, \mathrm{NB}=5 \%)$ and resting $(\mathrm{AB}=28 \%, \mathrm{NB}=23 \%)$ were significantly different between the two areas ( $\mathrm{AB}>\mathrm{NB}$, Figs 3 and 4).

Mother and calf resting and tail-up displays were very significantly different between the two areas. However, the greatest difference between the two areas was for aggressive 


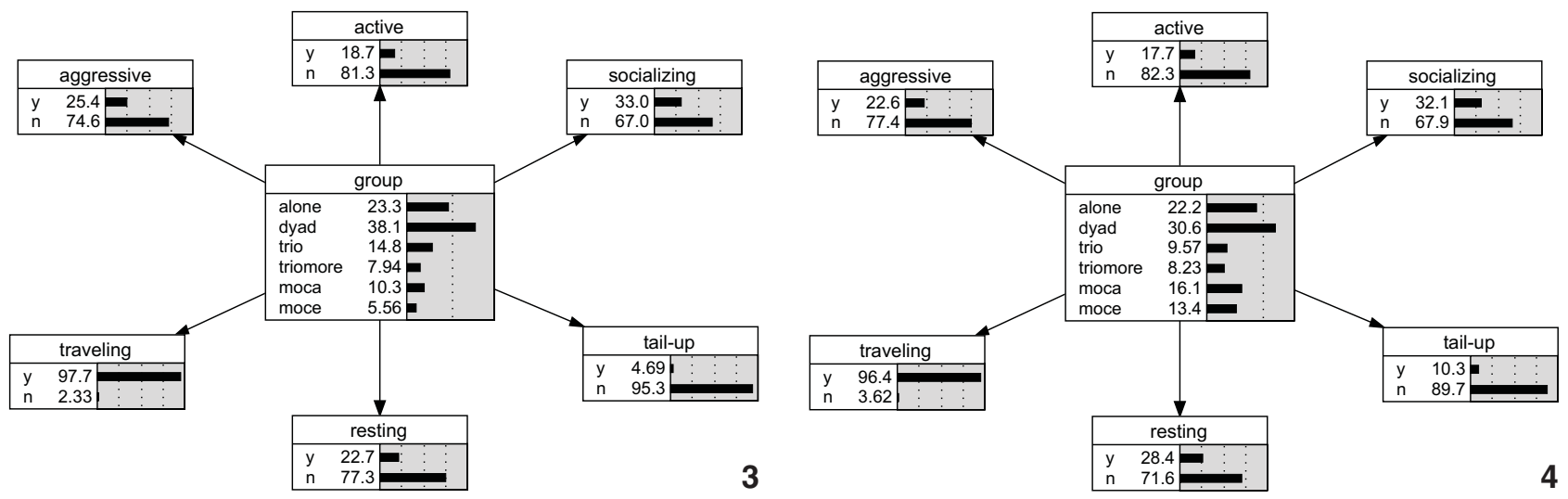

Figures 3-4. Model of the Bayesian net that summarizes the probabilities of occurrence of the behaviors observed at the northern coast of Bahia (3) and the Abrolhos Bank (4), from 2001 to 2003. Codes for group composition are: an alone individual (alone), two adults (dyad), three adults (trio), more than three (triomore), mother and calf (moca), mother, calf, and escort (moce). The " $y$ " corresponds to occurrences and " $\mathrm{n}$ " to the non-occurrence of the behavior.

behavior in mother, calf and escort (difference of 12\%, Table I). Also, the frequency of tail-up displays was greater in $\mathrm{AB}$ $\left(\chi^{2}=41.4, \mathrm{p}<0.001 ;\right.$ Table II).

\section{DISCUSSION}

Groups more commonly had calves at Abrolhos Bank, possibly because environmental conditions are more favorable for reproduction and calf-rearing, such as shallow and warm waters protected by coral reefs. Also, many observations in this study took place near the Abrolhos Archipelago, where waters are shallow, protected and females are often seen with calves (Morete et al. 2007).
In comparison, the northern coast of Bahia are characterized by a narrow continental shelf, reaching its minimum of $8 \mathrm{~km}$ at Ilheus. At Abrolhos, the shelf is up to $190 \mathrm{~km}$ wide (CASTRO \& Miranda 1998), hence waters at NB are much deeper on average. Mother and calf groups were seen at around $2 \mathrm{~km}$ offshore at two different times during 2002 and 2003 at Praia do Forte (NB), which suggests to us that they were searching for shallower areas. Evidence suggests that mother-calf groups prefer shallow waters and coasts at all latitudes (CLAPHAM 2000). This choice may reduce predation risk due to sharks (WHITEHEAD \& Moore 1982, Mattila \& Clapham 1989).

Also, Abrolhos Bank has greater protection than does the

Table I. Occurrence probabilities for behaviors based on the Bayesian net, at the northern coast of Bahia and Abrolhos Bank (2001-2003), by group: an alone individual (Alone), two adults (Dyad), three adults (Trio), more than three (Triomore), mother and calf (Moca), mother, calf, and escort (Moce).

\begin{tabular}{|c|c|c|c|c|c|c|c|}
\hline Behavior & Alone & Dyad & Trio & Triomore & Moca & Moce & Mean \pm SD \\
\hline \multicolumn{8}{|c|}{ Northern coast Bahia } \\
\hline Traveling & 96.6 & 99.3 & 98.2 & 96.8 & 95.0 & 95.5 & $96.9 \pm 1.62$ \\
\hline Resting & 23.6 & 22.1 & 21.1 & 6.45 & 32.5 & 31.8 & $22.9 \pm 9.45$ \\
\hline Tail-up & 8.99 & 3.45 & 3.51 & 3.23 & 2.50 & 4.55 & $4.37 \pm 2.36$ \\
\hline Socializing & 20.2 & 32.4 & 50.9 & 54.8 & 22.5 & 31.8 & $35.4 \pm 14.4$ \\
\hline Active & 11.2 & 17.2 & 29.8 & 38.7 & 7.50 & 22.7 & $21.2 \pm 11.7$ \\
\hline Aggressive & 10.1 & 20.0 & 43.9 & 77.4 & 12.5 & 27.3 & $31.9 \pm 25.4$ \\
\hline \multicolumn{8}{|l|}{ Abrolhos Bank } \\
\hline Traveling & 92.5 & 98.5 & 98.4 & 99.0 & 94.6 & 97.1 & $96.7 \pm 2.59$ \\
\hline Resting & 24.9 & 29.1 & 18.9 & 4.76 & 41.2 & 38.2 & $26.2 \pm 13.4$ \\
\hline Tail-up & 13.2 & 10.8 & 6.56 & 2.86 & 10.8 & 11.2 & $9.24 \pm 3.80$ \\
\hline Socializing & 21.4 & 30.7 & 52.5 & 58.1 & 28.9 & 26.5 & $36.4 \pm 15.1$ \\
\hline Active & 11.4 & 16.5 & 27.9 & 37.1 & 13.7 & 16.5 & $20.5 \pm 9.91$ \\
\hline Aggressive & 9.25 & 20.9 & 48.4 & 77.1 & 6.86 & 15.9 & $29.7 \pm 27.6$ \\
\hline
\end{tabular}

Revista Brasileira de Zoologia 25 (2): 159-164, June, 2008 
Table II. Groups of humpback whales observed at the northern coast of Bahia and Abrolhos Bank (2001-2003), with respect to year and number of tail-up displays.

\begin{tabular}{|c|c|c|c|c|c|c|}
\hline \multirow{2}{*}{ Years } & \multicolumn{3}{|c|}{ Northern coast Bahia } & \multicolumn{3}{|c|}{ Abrolhos Bank } \\
\hline & Number of groups & Number of displays & $\%$ & Observed groups & Occurrence & $\%$ relative \\
\hline 2001 & 55 & 0 & 0 & 344 & 74 & 21.5 \\
\hline 2002 & 111 & 6 & 5.4 & 273 & 39 & 14.3 \\
\hline 2003 & 212 & 6 & 2.8 & 302 & 35 & 11.6 \\
\hline Total & 378 & 12 & $3.2^{\star}$ & 919 & 148 & $16.1^{*}$ \\
\hline
\end{tabular}

northen coast. The northen coast is a protected area (since 2003) while Abrolhos Bank is a national marine park (since 1983) and is better protected by Brazilian law.

Competitive groups without calves were larger in Abrolhos, which may be due to the greater density there (1.6-2.3 individuals per square nautical mile) than at the north coast (0.3-1.0 individuals per square nautical mile) (C.C.A. Martins , pers. comm.). It has been suggested that variation in population density may be associated with variation in interactions among individuals, such that density and interactions are positively correlated (BAKER \& HERMAN 1984). Agonistic interactions (tail slashes, head-lunging, bubblestreams) were more common in groups of four or five adults without calves as compared to groups of less than four adults with calves (TYACK \& WHiteHEAD 1983). Also, a seasonality may influence aggression. During March, 24\% of groups were involved in aggressive interactions, while during January, February and April, 16\% or less were involved in aggression (BAKER \& HERMAN 1984).

\section{Typical behavior patterns differ in the two areas}

Traveling, socializing, active and aggressive behaviors were very similar (differences less than $4 \%$ ) in the two areas. Tail-up and resting occurred more often in Abrolhos Bank (differences between 4-8\%). Tail-up display is commonly followed by resting at Abrolhos and the tail-up display seems to be more common at Abrolhos than other areas (MORETE et al. 2003). Thus, despite the fact that these two areas are distant and distinct (different depths, temperatures and continental shelf width), behaviors are very similar in the two locations. Only groups with calves, resting and tail-up displays were different between the two areas. Perhaps these differences are due to the differences in legal protection status of the two locations.

The stimulus for aggressive behaviors is still uncertain. Perhaps they are due to proximity to boats and perhaps not all behaviors, such as bubblestreams, are actually involved with aggressive interactions. Socializing behavior may also be due to a variety of reasons. For example, breaching is commonly described in the context of socializing, but here we observed breaching in alone individuals, and so may indicate multiple functions (WHITEHEAD 1985).

While there are no sightings published of the same whale found at both locations, it is quite probable that transit be- tween the two areas is not uncommon, both due to proximity of the two and due to the migration route (see Zerbini et al. 2006). Therefore, here we suggest that these are not subpopulations, but rather differences between the two locations are probably due to the kinds of groups that use each area, such as groups with calves, which may prefer the shallow and protected waters found at Abrolhos Bank and nearby.

\section{ACKNOWLEDGEMENTS}

We thank Petrobras S.A. for supporting the observation boats; CNPq for the fellowship for D.G. Lunardi (Programa de Pós-Graduação em Ecologia, Universidade de Brasília); and J.S. Marinho-Filho, V.F. Saracura, P.C.A. Simões-Lopes and an anonymous reviewer. We also thank the Instituto Baleia Jubarte for allowing us to use the data from NB and AB (2001 to 2003), L. Wedekin and M.C.C. Marcondes for comments on the manuscript and S. Más-Rosa, E. Marcovaldi, B. Bastos, C.G. Baracho, A.C. Freitas, C.C.A. Martins, M. Rossi, M. Galiza, L. Pacheco and all the interns of the Humpback Whale Project for their help in data collection.

\section{LITERATURE CITED}

Altmann, J. 1974. Observational study of behavior: sampling methods. Behaviour 49: 227-265.

BAKER, C.S. \& L.M. Herman. 1984. Aggressive behavior between humpback whales (Megaptera novaeangliae) wintering in Hawaiian waters. Canadian Journal of Zoology 62 (10): 1922-1937.

Castro, B.M. \& L.B. Miranda. 1998. Physical oceanography of the Western Atlantic continental shelf located between $4^{\circ} \mathrm{N}$ and $34^{\circ} \mathrm{S}$, coastal segment $(4, \mathrm{~W})$, p. 209-251. In: A.R. Robinson $\&$ K.H. Brink (Eds). The Sea. New York, John Wiley, vol. 11, 1080 p.

CHARniak, E. 1991. Bayesian networks without tears. Artificial Intelligence Magazine 12: 50-63.

Chittleborough, R.G. 1958. The breeding cycle of the female humpback whale, Megaptera nodosa (Bonnaterre). Australian Journal Marine Freshwater Research 9: 1-18.

Chittleborough, R.G. 1965. Dynamics of two populations of the humpback whale, Megaptera novaeangliae (Borowski). Australian Journal Marine Freshwater Research 16: 33-128.

Revista Brasileira de Zoologia 25 (2): 159-164, June, 2008 
Clapham, P.J. \& C.A. Mayo. 1987. Reproduction and recruitment of individually identified humpback whales, Megaptera novaeangliae, observed in Massachusetts Bay, 1979-1985. Canadian Journal of Zoology 65: 2853-2863.

Clapham, P.J. \& C.A. Mayo. 1990. Reproduction of humpback whales, Megaptera novaeangliae, observed the Gulf of Maine. Reports of the International Whaling Comission Special Issue 12: 171-175.

Clapham, P.J. 2000. The humpback whale: seasonal feeding and breeding in baleen whale, p. 173-196. In: J. ManN; R.C. Connor; P.L. Tyack \& H. WhitehEAd (Eds). Cetacean Societies - field studies of dolphins and whales. Chicago, University of Chicago Press, XIV+433p.

Clapham, P.J.; P.J. Palsbøll; D.K. Mattila \& O. Vasquez. 1992. Composition and dynamics of humpback whale competitive groups in the West Indies. Behaviour 122 (3): 182-194.

Corkeron, P.J. 1995. Humpback whales (Megaptera novaeangliae) in Hervey Bay, Queensland: behaviour and responses to whale-watching vessels. Canadian Journal of Zoology 73 (7): 1290-1299.

Dawbin, W.H. 1966. The seasonal migratory cycle of humpback whales, p. 145-170. In: K. S. Norris (Ed.). Whales, dolphins and porpoises. Los Angeles, University of California Press, $\mathrm{XV}+789 \mathrm{p}$.

ERsts, P. \& H.C. Rosenbaum. 2003. Habitat preference reflects social organization of humpback whales (Megaptera novaeangliae) on a wintering ground. Journal of Zoology 260: 337-345.

Fainstein, R. \& C.P. Summerhayes. 1982. Structure and origin of marginal banks off Eastern Brazil. Marine Geology 46: 199215.

Krebs, J.R. \& N.B. Davies. 1996. Introdução à Ecologia Comportamental. São Paulo, Atheneu, V+420p.

Martins, C.C.A.; M.E. Morete; M.H. Engel; A.C. Freitas; E.R. Secchi $\&$ P.G. KINAs. 2001. Aspects of habitat use patterns of humpback whales in the Abrolhos Bank, Brazil, breeding ground. Memoirs Queensland Museum 47: 563-570.

Mattila, D.K. \& P.J. Clapham. 1989. Humpback whales, Megaptera novaeangliae, and other cetaceas on Virgin Bank and in the northern Leeward Islands, 1985 and 1986. Canadian Journal of Zoology 67: 2201-2211.

Mattila, D.K.; P.J. Clapham; O. Vasquez \& R. Bowman. 1994. Occurrence, population composition and habitat use of humpback whales in Samana Bay, Dominican Republic. Canadian Journal of Zoology 72: 1898-1907.

Mobley, J.M. \& L.M. Herman. 1985. Transience of social affiliations among humpback whales (Megaptera novaeangliae) in the Hawaiian wintering grounds. Canadian Journal of Zoology 63: 762-772.

Morete, M.E.; A. Freitas; M.H. Engel; R.M. Pace III \& P.J. Clapham. 2003. A novel behavior observed in humpback whales on wintering grounds at Abrolhos Bank (Brazil). Marine Mammal Science 19 (4): 694-707.

Morete, M.E.; T.L. Bisi \& S. Rosso. 2007. Temporal pattern of humpback whale (Megaptera novaeangliae) group structure around Abrolhos Arquipelago breeding region, Bahia, Brazil. Journal of the Marine Biological Association of United Kingdom 87: 87-92.

Palsbøll, P.J.; J. Allen; M. Bérubé; P.J. Clapham; T.P. Feddersen; P. Hammond; H. Jørgensen; S. Katona; A.H. Larsen; F. Larsen; J. Lien; D.K. Mattila; J. Sigurjónsson; R. Sears; T. Smith; R. Sponer; P. Stevick \& N. Øien. 1997. Genetic tagging of humpback whales. Nature 388 (6644): 767-769.

Robbins, J.; M. Bérubé; P. Clapham; N. Friday \& D. Mattila. 2001. Structure and regional composition of the Gulf of Maine humpback whale (Megaptera novaeangliae) population. IWC Conference, C/53/NAH12, p. 1-11.

TYACK, P. \& H.P. WHITEHEAD. 1983. Male competition in large groups of wintering humpback whales. Behaviour 83: 132-154.

WeInRICH, M. 1998. Early experience in habitat choice by humpback whales (Megaptera novaeangliae). Journal of Mammalogy 79 (1): 163-170.

Whitehead, H.P. \& M.J. Moore. 1982. Distribution and movements of West Indian humpback whales in winter. Canadian Journal of Zoology 60: 2203-2211.

WhiteHEAD, H.P. 1983. Structure and stability of humpback whale groups off Newfoundland. Canadian Journal of Zoology 61: 1391-1397.

WHITEHEAD, H.P. 1985. Humpback whale breaching. Investigations on Cetacea 17: 117-155.

Zerbini, A.N.; A. Andriolo; M.P.Heide-Jorgensen; J.L. Pizzorno; Y.G. Maia; G.R. Vanblaricom; D.P. Demaster; P.C. Simões-Lopes; S. Moreira \& C. Bethlem. 2006. Satellite-monitored movements of humpback whales Megaptera novaeangliae in the Southwest Atlantic Ocean. Marine Ecology Progress Series 313: 295-304.

Submitted: 05.IV.2007; Accepted: 21.V.2008.

Editorial responsibility: Lena Geise 